Check for updates

The BMJ

Cite this as: $B M J 2020 ; 370: m 3720$ http://dx.doi.org/10.1136/bmi.m3720 Published: 23 September 2020

\section{Covid-19: Risk of death more than doubled in people who also had flu, English data show}

\section{Gareth lacobucci}

People infected with both flu and SARS-CoV-2 are more than twice as likely to die as someone with the new coronavirus alone, emerging evidence from England has shown.

An analysis by Public Health England (PHE) of cases from January to April 2020 also found that people with the two viruses were more at risk of severe illness. Most cases of coinfection were in older people, and more than half of them died.

The data, published as a preprint on medRxiv, ${ }^{1}$ were released as PHE launched an expanded flu vaccination programme for England that will target 30 million people this winter.

Jonathan Van-Tam, England's deputy chief medical officer, told a PHE media briefing, "There is now some emerging evidence which clearly suggests that coinfection with influenza and covid-19 produces bad outcomes. One of these diseases is currently vaccine preventable, and that's the really important point."

PHE's negative case-control study, which has not been peer reviewed, compared rates of coinfection and estimated the impact on mortality. It looked at 19256 people who were tested for both flu and SARS-CoV-2 from 20 January to 25 April 2020.

It found 58 people with coinfection, among whom the mortality rate was $43.1 \%$ (25). Of those who died, $80 \%$ (20) were aged over 70 .

\section{"Interaction effect"}

The odds of death were 2.27 times as high (95\% confidence interval 1.23 to 4.19) as in people with SARS-CoV-2 alone and were 5.92 times (3.21 to 10.91) the odds in people with neither flu nor SARS-CoV-2. The authors said that this suggested "possible synergistic effects" in coinfected people.

The risk of testing positive for SARS-CoV-2 was 58\% lower among flu positive cases. PHE said that this was consistent with recent findings from New York, where under $3 \%$ of people testing positive for SARS-CoV-2 had coinfection with flu, whereas 13\% of those testing negative for SARS-CoV-2 were flu positive. $^{2}$

PHE's study incorporated intensive care admission and ventilator use as additional indicators of severe disease. When combining ventilator use or death into a composite variable, the odds of death were 6.43 times greater in people with coinfection (3.61 to 11.47) than in those with neither virus. And when combining intensive care admission or death into a composite variable, the odds of death were 6.33 times greater in people with coinfection (3.57 to 11.23) than in those with neither virus.
The authors said that this showed strong evidence of viruses acting independently. But the findings could not distinguish between a reduced risk of SARS-CoV-2 in people first infected with flu or vice versa.

\section{Flu protection}

PHE said longstanding evidence showed that being infected with one respiratory virus meant that people were less likely to be infected with another in the short term. But it said that more research was needed to understand the relation between flu and SARS-CoV-2 because flu came early last winter, so the two did not overlap much.

Yvonne Doyle, medical director of PHE, told the briefing, "There is some evidence to suggest that flu and covid and other viruses may compete with each other. [But] if you get both, you are in some serious trouble. And the people who are most likely to get both may be the very people that can least afford to."

Doyle said that PHE's data provided "an important signal" about the need for people to protect themselves against flu this year.

She said, "Most of the [other] studies on flu and covid are case reports and may be subject to publication bias, but this particular piece of work looked at death records, hospitalisation records, and infection records from laboratories. So, we are pretty confident that it reflects what actually had happened.

"This campaign will reinforce the importance of taking flu seriously this year and not being complacent about that."

Correction: PHE alerted us to an error in the preprint cited. The risk of testing positive for SARS-CoV-2 was actually $58 \%$ lower among flu positive cases, not 68\%. We corrected this on 25 September 2020.

Stowe J, Tessier E, Zhao H, et al. Interactions between SARS-CoV-2 and influenza and the impact of coinfection on disease severity: a test negative design. medRxiv (preprint) 2020 Sep 18. https://www.medrxiv.org/content/10.1101/2020.09.18.20189647v1.full.pdf.

2 Nowak MD, Sordillo EM, Gitman MR, Paniz Mondolfi AE. Co-infection in SARS-CoV-2 infected patients: where are influenza virus and rhinovirus/enterovirus?) Med Virol 2020 doi: 10.1002/jmv.25953. pmid: 32352574

This article is made freely available for use in accordance with BMJ's website terms and conditions for the duration of the covid-19 pandemic or until otherwise determined by BMJ. You may use, download and print the article for any lawful, non-commercial purpose (including text and data mining) provided that al copyright notices and trade marks are retained. an interaction effect when compared with the two 